\title{
In vitro Photoprotective Evaluation and Development of Novel Nanoemulsion with Chromone Derivative
}

\author{
Amanda S. Antunes, ${ }^{a}$ Ana Paula Gouveia, ${ }^{a}$ Gabriela M. Diogo, ${ }^{a}$ Jason G. Taylor, ${ }^{a}$ \\ Lucas R. D. Sousa, ${ }^{a}$ Tatiane R. Amparo, ${ }^{b}$ Fernanda B. Perasoli, ${ }^{b}$ \\ Orlando D. H. dos Santos, ${ }^{b}$ Thiago Cazati, ${ }^{\circ}$ Paula M. A. Vieira, ${ }^{d}$ \\ Ricardo G. Penido ${ }^{e}$ and Viviane M. R. dos Santos ${ }^{\oplus} *, a$ \\ ${ }^{a}$ Departamento de Química, Instituto de Ciências Exatas e Biológicas, \\ Universidade Federal de Ouro Preto, 35400-000 Ouro Preto-MG, Brazil \\ ${ }^{b}$ Escola de Farmácia, Universidade Federal de Ouro Preto, 35400-000 Ouro Preto-MG, Brazil \\ ${ }^{c}$ Departamento de Física, Instituto de Ciências Exatas e Biológicas, \\ Universidade Federal de Ouro Preto, 35400-000 Ouro Preto-MG, Brazil \\ ${ }^{d}$ Departamento de Ciências Biológicas, Universidade Federal de Ouro Preto, \\ 35400-000 Ouro Preto-MG, Brazil \\ ${ }^{e}$ Departamento de Química, Universidade Federal de Minas Gerais, \\ 31270-901 Belo Horizonte-MG, Brazil
}

\begin{abstract}
Chromone derivatives exhibiting high absorbance values in the UVA/UVB region were synthesized, and their photoprotective properties were evaluated. Chromones were prepared according to known literature procedures and characterized by high resolution mass spectrometry, infrared (IR) and nuclear magnetic resonance (NMR) spectroscopy. The in vitro solar protection factor (SPF) was determined by the Mansur method and cytotoxicity was evaluated using the sulforhodamine B assay. Two of the chromones synthesized demonstrated suitable SPF values and displayed no cytotoxic effect towards MRC-5 human fibroblasts at the tested concentrations, indicating great potential for future in vivo assays and clinical trials. Finally, the lead compound was incorporated into a nanoemulsion. Nanoemulsions showed high droplet size homogeneity and excellent stability. Chromones bearing methoxy substituents were found to be the most promising compounds with ideal photoprotective properties desirable for utilization and incorporation in sunscreen formulations.
\end{abstract}

Keywords: Mansur, chromone, organic UV filters, cytotoxicity, nanoemulsion

\section{Introduction}

Exposure to sun light and its UV radiation ${ }^{1,2}$ is a contributing factor to developing cutaneous malignant melanoma which is one of the fastest growing types of cancer cases. ${ }^{1}$ UVB radiation causes the formation of reactive oxygen species (ROS) in the skin and increases oxidative stress, resulting in destructive damage and loss of cellular function. In addition, UVB induces genetic mutation, inflammation, and skin cancer. ${ }^{3}$ Sunscreens contain either UV blockers or filters, which have the ability to block or absorb solar radiation. Scientists and cosmetic companies

*e-mail: vivianesantos@ufop.edu.br are continually working to develop new UV filters with high stability under ultraviolet (UV) exposure that can be incorporated into sunscreens. ${ }^{4}$ UV filter benzophenone-3, also known as oxybenzone, is commonly used in sunscreen products and is suspected to act as a weak estrogen. Studies revealed that oxybenzone caused increased uterine weight in rat researches and increased proliferation of human breast cancer cells in vitro. ${ }^{5}$ Due to these limitations, studies have been carried out towards the development of new compounds with photoprotective applications. For example, octocrylene analogues, bis(indolyl)methane derivatives, vanillin derivatives, bile acids/azastilbenes conjugates, $N$-acyl hydrazone compounds, benzophenone derivatives and quercetin derivatives have all been 
investigated as potential alternatives. ${ }^{6-14}$ In vitro methods used for the evaluation and development of new active ingredients are currently accepted and present advantages to in vivo methods such as reproducibility, simplicity and no need for human subjects. The photoprotective activity is expressed as its sun protection factor (SPF) and is a convenient way of correlating the dose of sun exposure with the concentration of the photoprotective product applied without the occurrence of erythema. ${ }^{6}$ Sunscreens can differ in their pharmaceutical forms and may be purchased as: oils, gels, emulsions, among others. ${ }^{15}$ The growth in interest for the development of cosmetic nanoemulsions for application in topical cosmetic products is due to their ability to allow controlled delivery and optimized dispersion of active ingredients into the desired layers of the skin such as the epidermis. The active ingredients in the form of nanoparticles have a high surface-to-volume ratio, which promotes dispersibility in the emulsion, and they are therefore better adapted for multiple functions. ${ }^{16}$ This technology has found its way into commercial preparations of cosmetic products. Chromones represent a class of natural products that have displayed a variety of biological activities, including antifungal, anti-microbial, anti-allergenic, antitubulin, antiviral, anti-hypertensive, antitumoral activities ${ }^{6-9}$ but up until now, they have not been explored for their photoprotective properties. The aim of this research therefore was to synthetize and evaluate the potential of chromones for innovative sunscreens and to determine their sun protection factor (SPF).

\section{Experimental}

Reagents and solvents (Sigma-Aldrich, St. Louis, USA) were used without further purification and were purchased from commercial suppliers. The melting points were valued on the Büchi Melting Point B-540 (Merck KGaA, Darmstadt, Germany). The nuclear magnetic resonance (NMR) spectra were acquired on a $400 \mathrm{MHz}$ NMR, Nuclear Bruker Ascend 400 Instrument (Billerica, Massachusetts, USA). ${ }^{1} \mathrm{H}$ and ${ }^{13} \mathrm{C}$ NMR spectra of these compounds are available in the Supplementary Information (SI) section. Infrared spectra were obtained on a Thermo Scientific Nicolet 380 FT-IR apparatus $\left(600-4000 \mathrm{~cm}^{-1}\right.$, Nicolet Instrument Corp., Madison, WI, USA) using the potassium bromide ( $\mathrm{KBr}$, spectroscopic grade) disc method. The in vitro solar protection factor (SPF) and photostability were determined by the spectrophotometric method developed by Mansur et al. ${ }^{17}$ The UV-Vis ultraviolet readings were determined on the Thermo Scientific Genesys 10S spectrophotometer (Waltham, Massachusetts, USA). The average size, polydispersity index and zeta potential of the nanoemulsions were determined by photon correlation spectroscopy and microelectrophoresis associated with laser-Doppler anemometry on the Zetasizer (Malvern, model Zetasizer Nano series-Nano ZS, Malvern, United Kingdom). High resolution mass spectra (HRMS) were acquired using a LCMS-Q-ORBITRAP (Thermo Scientific, Fair Lawn, NJ, USA) mass spectrometer and the samples were solubilized in acetonitrile. The high-performance liquid chromatography (HPLC) was bypassed and the samples were directly injected into the mass spectrometer.

Typical procedure for synthesis of esters (1a-1c)

In a round bottom flask $(50 \mathrm{~mL}), 5 \mathrm{~mL}$ of pyridine, $2.5 \mathrm{~mL}(1.77 \mathrm{mmol})$ of 2-hydroxyacetophenone and $2.0 \mathrm{~mL}(1.42 \mathrm{mmol})$ of the requisite benzoyl chloride were added. The reactants were stirred for approximately $15 \mathrm{~min}$ at $25^{\circ} \mathrm{C}$. After this time, $1 \mathrm{M} \mathrm{HCl}(60 \mathrm{~mL})$ was added followed by crushed ice. Next, the solid was filtered and the precipitate was washed with methanol and water (1:1). The powder was recrystallized with methanol to provide white crystals. For esters 1a-1c, the NMR spectra were compared with values reported in the literature. ${ }^{18,19}$

\section{2-Acetylphenyl benzoate (1a)}

Product yield $71 \%$; mp 86-87 ${ }^{\circ} \mathrm{C}$ (lit 87-88 ${ }^{\circ} \mathrm{C}$ ); ${ }^{20}$ ${ }^{1} \mathrm{H}$ NMR (400 MHz, $\left.\mathrm{CDCl}_{3}\right) \delta 2.55(\mathrm{~s}, 3 \mathrm{H}), 7.23(\mathrm{~d}, 1 \mathrm{H}$, $J 8.0 \mathrm{~Hz}), 7.34(\mathrm{t}, 1 \mathrm{H}, J 7.5 \mathrm{~Hz}), 7.55-7.60(\mathrm{~m}, 4 \mathrm{H}), 7.86$ $(\mathrm{dd}, 1 \mathrm{H}, J 8.0$ and $1.5 \mathrm{~Hz}), 8.21-8.24(\mathrm{~m}, 2 \mathrm{H}) ;{ }^{13} \mathrm{C} \mathrm{NMR}$ $\left(100 \mathrm{MHz}, \mathrm{CDCl}_{3}\right) \delta 29.8,123.9,126.2,128.7,129.3$, $130.3,130.4,131.4,133.5,133.9,149.4,165.2$, 197.6.

\section{2-Acetylphenyl-3,4-dimethoxybenzoate (1b)}

Product yield $86 \%$; mp $129-131{ }^{\circ} \mathrm{C}$ (lit $129-131{ }^{\circ} \mathrm{C}$ ); ${ }^{21}$ ${ }^{1} \mathrm{H}$ NMR (400 MHz, $\mathrm{CDCl}_{3}$ ) $\delta 2.57$ (s, 3H), 3.98 (s, 6H), 6.98-7.91 (m, 7H); ${ }^{13} \mathrm{C}$ NMR (100 MHz, $\left.\mathrm{CDCl}_{3}\right) \delta 29.9$, $56.0,110.5,112.5,121.6,123.9,130.2,148.9,153.8$, 164.9, 197.7.

\section{2-Acetylphenyl-4-nitrobenzoate (1c)}

Product yield 85\%; mp 91-92 ${ }^{\circ} \mathrm{C}$ (lit 93-95 ${ }^{\circ} \mathrm{C}$ );22 ${ }^{1} \mathrm{H}$ NMR (400 MHz, $\left.\mathrm{CDCl}_{3}\right) \delta 2.59$ (s, 3H), $7.27(\mathrm{~d}, 1 \mathrm{H}$, $J 9.0 \mathrm{~Hz}), 7.46(\mathrm{t}, 1 \mathrm{H}, J 7.7 \mathrm{~Hz}), 7.66(\mathrm{t}, 1 \mathrm{H}, J 7.6 \mathrm{~Hz}), 7.93$ (d, $1 \mathrm{H}, J 7.8 \mathrm{~Hz}), 8.38-8.42(\mathrm{~m}, 4 \mathrm{H}) ;{ }^{13} \mathrm{C}$ NMR $(100 \mathrm{MHz}$, $\left.\mathrm{CDCl}_{3}\right) \delta 29.1,123.8,126.7,130.8,133.9,148.9,150.9$, 163.6, 197.3.

Typical procedure for synthesis of diketones (2a-2c)

In a one necked round bottom flask $(50 \mathrm{~mL}), 0.470 \mathrm{~g}$ $(1.56 \mathrm{mmol})$ of ester $1 \mathrm{a}-1 \mathrm{c}, 1.10 \mathrm{~mL}$ of pyridine and 
$0.175 \mathrm{~g}$ ( $3.13 \mathrm{mmol})$ of $\mathrm{KOH}$ were added. The mixture was maintained under stirring for approximately $15 \mathrm{~min}$ at $50{ }^{\circ} \mathrm{C}$. Upon completion, the reaction was cooled in an ice bath and acetic acid $10 \%$ was added resulting in the precipitation of a yellow solid. The solid was filtered and washed with cold ethanol and recrystallized with $70 \%$ aqueous ethanol to afford a yellow powder. Diketones 2a-2c were confirmed by comparison of their melting points to the literature values. NMR spectra was not carried out due to the keto-enol tautomerism that occurs readily in $\mathrm{CDCl}_{3}$.

1-(2-Hydroxyphenyl)-3-phenylpropane-1,3-dione (2a)

Product yield $77 \%$; mp $121-122{ }^{\circ} \mathrm{C}$ (lit $118-120{ }^{\circ} \mathrm{C}$ ). ${ }^{23}$

1-(3,4-Dimethoxyphenyl)-3-(2-hydroxyphenyl)propane1,3-dione (2b)

Product yield $89 \%$; mp $130-131{ }^{\circ} \mathrm{C}$ (lit $129-130{ }^{\circ} \mathrm{C}$ )..$^{24}$

1-(4-Nitrophenyl)-3-(2-hydroxyphenyl)propane-1,3-dione (2c)

Product yield $42 \% ; \mathrm{mp} 197-198{ }^{\circ} \mathrm{C}$ (lit 201-203 ${ }^{\circ} \mathrm{C}$ )..$^{25}$

Typical procedure for synthesis of chromones (3a-3c)

In a one necked round bottom flask $(50 \mathrm{~mL})$ equipped with stir bar and reflux condenser was added $2 \mathrm{mmol}$ of diketone 2a-2c, $2.4 \mathrm{mmol}$ of sodium acetate and $7 \mathrm{~mL}$ acetic anhydride. The mixture was stirred for $60 \mathrm{~min}$ at $140{ }^{\circ} \mathrm{C}$. Once accomplished, the reaction solution was poured in water and the precipitate formed was filtered and recrystallized with aqueous ethanol to provide 3-benzoylchromone derivatives $\mathbf{3 a - 3} \mathbf{c}$ as white solids.

\section{3-Benzoyl-2-methyl-4H-chromen-4-one (3a)}

Product yield $16.6 \%$; mp $118-119{ }^{\circ} \mathrm{C}$; UV-Vis (methanol) $\lambda / \mathrm{nm} \mathrm{365;} \mathrm{IR} \mathrm{(KBr)} v / \mathrm{cm}^{-1} 3000,1700$, 1650, 1500, 1450; ${ }^{1} \mathrm{H}$ NMR (400 MHz, $\mathrm{CDCl}_{3}$ ) $\delta 2.38$ (s, 3H, H12), 7.39-7.61 (m, 3H), $7.68(\mathrm{t}, 2 \mathrm{H}, J 8.4 \mathrm{~Hz})$, $7.71(\mathrm{t}, 1 \mathrm{H}, J 8.4 \mathrm{~Hz}), 7.90(\mathrm{~d}, 2 \mathrm{H}, J 7.6 \mathrm{~Hz}), 8.16(\mathrm{~d}, 1 \mathrm{H}$, $J 7.9 \mathrm{~Hz}) ;{ }^{13} \mathrm{C}$ NMR $\left(100 \mathrm{MHz}, \mathrm{CDCl}_{3}\right) \delta 29.7,117.9,123.1$, 125.5, 128.7, 130.0, 133.8, 136.9, 155.9, 165.4, 175.9, 193.9, according to Figures S1 and S2 (SI section); HRMS electrospray ionization time-of-flight (ESI-TOF) $\mathrm{m} / \mathrm{z}$, calcd. for $\mathrm{C}_{17} \mathrm{H}_{13} \mathrm{O}_{3}[\mathrm{M}+\mathrm{H}]^{+}:$265.0859, found: 265.0851.

3-(3,4-Dimethoxybenzoyl)-2-methyl-4H-chromen-4-one (3b)

Product yield $77 \%$; $\mathrm{mp} 182-183{ }^{\circ} \mathrm{C}$; UV-Vis (methanol) $\lambda / \mathrm{nm} \mathrm{365;} \mathrm{IR} \mathrm{(KBr)} v / \mathrm{cm}^{-1} 3000,1700,1650,1500$, 1450, 1250, 1000; ${ }^{1} \mathrm{H}$ NMR (400 MHz, $\mathrm{CDCl}_{3}$ ) $\delta 2.57$ (s, 3H), $3.99(\mathrm{~s}, 6 \mathrm{H}), 7.01(\mathrm{~d}, 2 \mathrm{H}, J 8.5 \mathrm{~Hz}) 7.25(\mathrm{~d}, 1 \mathrm{H}$,
$J 8.7 \mathrm{~Hz}), 7.37(\mathrm{t}, 1 \mathrm{H}, J 8.4 \mathrm{~Hz}), 7.61(\mathrm{~m}, 2 \mathrm{H}), 7.70(\mathrm{~d}$, $1 \mathrm{H}, J 2.0 \mathrm{~Hz}), 7.9(\mathrm{~m}, 2 \mathrm{H}) ;{ }^{13} \mathrm{C}$ NMR (100 MHz, $\left.\mathrm{CDCl}_{3}\right)$ $\delta 29.9,56.1,110.5,112.4,121.6,123.9,126.1,130.2$, 131.4, 133.4, 148.9, 149.5, 153.8, 164.9, 197.8, according to Figures S3 and S4 (SI section); HRMS (ESI-TOF) $\mathrm{m} / z$, calcd. for $\mathrm{C}_{19} \mathrm{H}_{17} \mathrm{O}_{5}[\mathrm{M}+\mathrm{H}]^{+}: 325.1071$, found: 325.1066.

2-Methyl-3-(4-nitrobenzoyl)-4H-chromen-4-one (3c)

Product yield $95 \% ; \mathrm{mp} 198-199^{\circ} \mathrm{C}$ (lit 202-204 ${ }^{\circ} \mathrm{C}$ ) $2^{25}$ UV-Vis (methanol) $\lambda / \mathrm{nm} \mathrm{365;} \mathrm{IR} \mathrm{(KBr)} v / \mathrm{cm}^{-1} 3000$, $1700,1650,1500,1450,1400,880 ;{ }^{1} \mathrm{H}$ NMR $(400 \mathrm{MHz}$, $\left.\mathrm{CDCl}_{3}\right) \delta 2.51(\mathrm{~s}, 3 \mathrm{H}), 7.46(\mathrm{t}, 1 \mathrm{H}, J 8.0 \mathrm{~Hz}), 7.53(\mathrm{~d}, 1 \mathrm{H}$, $J 9.0 \mathrm{~Hz}), 7.75(\mathrm{~m}, 2 \mathrm{H}), 8.03(\mathrm{~d}, 2 \mathrm{H}, J 9.0 \mathrm{~Hz}), 8.16(\mathrm{dd}$, $1 \mathrm{H}, J 8.0$ and $J 1.5 \mathrm{~Hz}), 8.32(\mathrm{~d}, 2 \mathrm{H}, J 8.9 \mathrm{~Hz}) ;{ }^{13} \mathrm{C} \mathrm{NMR}$ $\left(100 \mathrm{MHz}, \mathrm{CDCl}_{3}\right) \delta$ 19.4, 117.9, 122.0, 123.4, 123.9, 125.9, 126.0, 130.0, 134.6, 142.1, 150.4, 155.9, 167.9, 175.9, 192.8, according to Figures S5 and S6 (SI section); HRMS (ESI-TOF) $m / z$, calcd. for $\mathrm{C}_{17} \mathrm{H}_{12} \mathrm{NO}_{5}[\mathrm{M}+\mathrm{H}]^{+}$: 310.0710, found: 310.0708 .

Log P-octanol-water partition coefficient

The $\log \mathrm{P}$ octanol-water partition coefficient was calculated using the online Molinspiration program Interactive $\log \mathrm{P}$ calculator (software version v2015.01). ${ }^{26}$

Determination of absorbance maximum of the compounds $(3 a-3 c)$

For the determination of absorbance in the UVA and UVB region, $10 \mathrm{mg}$ of chromone derivative was diluted in $10 \mathrm{~mL}$ methanol, resulting a concentration of $1 \mathrm{mg} \mathrm{mL} \mathrm{m}^{-1}$ that was diluted in methanol again to afford diluted concentrations of $0.025,0.030,0.050,0.070$ and $0.1 \mathrm{mg} \mathrm{mL}^{-1}$, according to Figures S7 and S8 (SI section). The scanning was performed for each concentration between the wavelengths of 200 and $600 \mathrm{~nm}$ in the UV spectrophotometer, using quartz bucket with an optical way of $1 \mathrm{~cm}$. Methanol was used as white and the experiment was carried out in triplicate. ${ }^{13,14,17}$

In vitro determination of the sun protection factor (SPF) of compounds 3a-3c

The photoprotection afforded by topical sunscreens against solar ultraviolet radiation exposure can be determined in vivo or in vitro. In vitro methods involve the measurement of absorption or the transmission of UV radiation through sunscreens and are determined based on spectrophotometric analysis of dilute solutions. ${ }^{13,14,17}$ Mansur et al. ${ }^{17}$ developed a very simple mathematical 
equation, utilizing UV spectrophotometry and the equation S1 (SI section). Spectrophotometric readings were made in the diluted solutions $(0.025,0.030,0.050,0.070$ and $0.1 \mathrm{mg} \mathrm{mL}^{-1}$ ) at wavelengths of $290,295,300,305,310$, 315 and $320 \mathrm{~nm}$. The determined absorbances were then applied to the Mansur method for the respective conversions to SPF using equation S1. The SPF was calculated for each concentration by the spectrophotometric method developed by Mansur et al. ${ }^{17}$

\section{The photostability test}

The photostability was performed using a light chamber with a UVB lamp source at $365 \mathrm{~nm}$. Solutions of $0.07 \mathrm{mg} \mathrm{mL}^{-1}$ chromone (3a-3c) were prepared in methanol and placed in volumetric flasks without a cap and exposed to radiation for total time of $1 \mathrm{~h}$ and $15 \mathrm{~min}$, and evaluated at $15 \mathrm{~min}$ intervals upon exposure to UV radiation. The system was open during the irradiation. ${ }^{27}$

\section{Preparation of nanoemulsions}

The nanoemulsions were prepared according to the emulsion phase inversion (EPI) method. ${ }^{28}$ To obtain the formulations, the distilled water and the oily phase were heated separately at $75 \pm 2{ }^{\circ} \mathrm{C}$. The water was slowly poured into the oily phase and the system was maintained under constant stirring at a speed of $500 \mathrm{rpm}$. Stirring was preformed until a temperature of $25 \pm 2{ }^{\circ} \mathrm{C}$ was reached. After $24 \mathrm{~h}$, all formulations were macroscopically evaluated. The compositions tested for nanoemulsions are described in Table 1.

\section{Cell viability}

Human fibroblasts MRC-5 cells, cultivated in Roswell Park Memorial Institute (RPMI) 1640 medium, were distributed in 96-well microtiter plate using a density of $5 \times 10^{4}$ cell per well and after they were incubated at $37^{\circ} \mathrm{C}$ with $5 \%$ of $\mathrm{CO}_{2}$ for $24 \mathrm{~h}$. Cells were treated with the sample dissolved in RPMI 2\% dimethyl sulfoxide (DMSO), at concentrations ranging from 1000 to $62.5 \mu \mathrm{g} \mathrm{mL} \mathrm{m}^{-1}$. The cell viability was evaluated using the sulforhodamine $\mathrm{B}$ assay (SRB). ${ }^{28}$ After $24 \mathrm{~h}$ incubation, the media was removed and cells were fixed with cold $20 \%$ trichloroacetic acid for $1 \mathrm{~h}$ at $4{ }^{\circ} \mathrm{C}$. The microtiter plate was washed with distilled water and dried. Thereafter, fixed cells were stained for $30 \mathrm{~min}$ with $0.1 \%$ SRB dissolved in $1 \%$ acetic acid. The plate washed again with $1 \%$ acetic acid, again allowed to dry and $200 \mu \mathrm{L}$ of $10 \mathrm{mM}$ TRIS buffer ( $\mathrm{pH} 10.5$ ) were added to stain solubilization at room temperature for about $30 \mathrm{~min}$. Samples absorbance was read in the spectrophotometer $(490 \mathrm{~nm})$ and the data were presented as the percentage of viable cells over untreated cells. ${ }^{28}$

\section{Statistical analysis}

The results were statistically analyzed by the oneway analysis of variance (ANOVA) test ${ }^{29}$ and multiple comparison by Tukey considering a significance level of $0.05(p<0.05)$. All statistical analysis was made using Graph Pad Prism 5.0 software. ${ }^{30}$

\section{Results and Discussion}

\section{Synthesis of compounds $\mathbf{3 a - 3 c}$}

Esterification of 2-hydroxyacetophenone with benzoyl chlorides initially yielded intermediates 1a-1c, which were then subjected to a Baker-Venkataraman rearrangement in pyridine and potassium hydroxide to afford the expected 1,3-diketones 2a-2c (Scheme 1). Comparison of NMR spectral data and melting point values with literature values (see Experimental section) confirmed the identity of esters 1a-1c and 1,3-diketones 2a-2c which are all known compounds. The reaction of 1,3-diketones $\mathbf{2 a - 2} \mathbf{c}$ with acetic anhydride and sodium acetate provided 3-benzoylchromone derivatives 3a-3c. Only chromone $\mathbf{3 b}$ is a novel compound. Products $\mathbf{3 a - 3 c}$ were characterized by high resolution mass spectrometry, Fourier transform infrared (FTIR) and ${ }^{1} \mathrm{H}$ and ${ }^{13} \mathrm{C}$ nuclear magnetic resonance spectroscopy. In the case of the FTIR analysis, the absorption band at

Table 1. Compositions tested to obtain nanoemulsions with compound $\mathbf{3 a - 3 \mathbf { c }}$ and standards

\begin{tabular}{lccccc}
\hline & $\begin{array}{c}\text { Nanoemulsion } \\
\text { with 3a / } \%\end{array}$ & $\begin{array}{c}\text { Nanoemulsion } \\
\text { with 3b / } \%\end{array}$ & $\begin{array}{c}\text { Nanoemulsion } \\
\text { with S1 / } \%\end{array}$ & $\begin{array}{c}\text { Nanoemulsion } \\
\text { with S2 / \% }\end{array}$ & Phase \\
\hline Span 120-LQ-(MH) & 4 & 4 & 4 & 4 & O \\
Ultramona RH 400 & 6 & 6 & 6 & 6 & O \\
Licuri oil & 10 & 10 & 10 & 10 & O \\
Distilled water & q.s.p & q.s.p & q.s.p & q.s.p & A \\
\hline
\end{tabular}

q.s.p: amount sufficient to complete $100 \mathrm{~mL}$; O: oily: A: aqueous; S1 (standard 1): Neo Heliopan ${ }^{\circledR}$ : S2 (standard 2): benzophenone-3. 

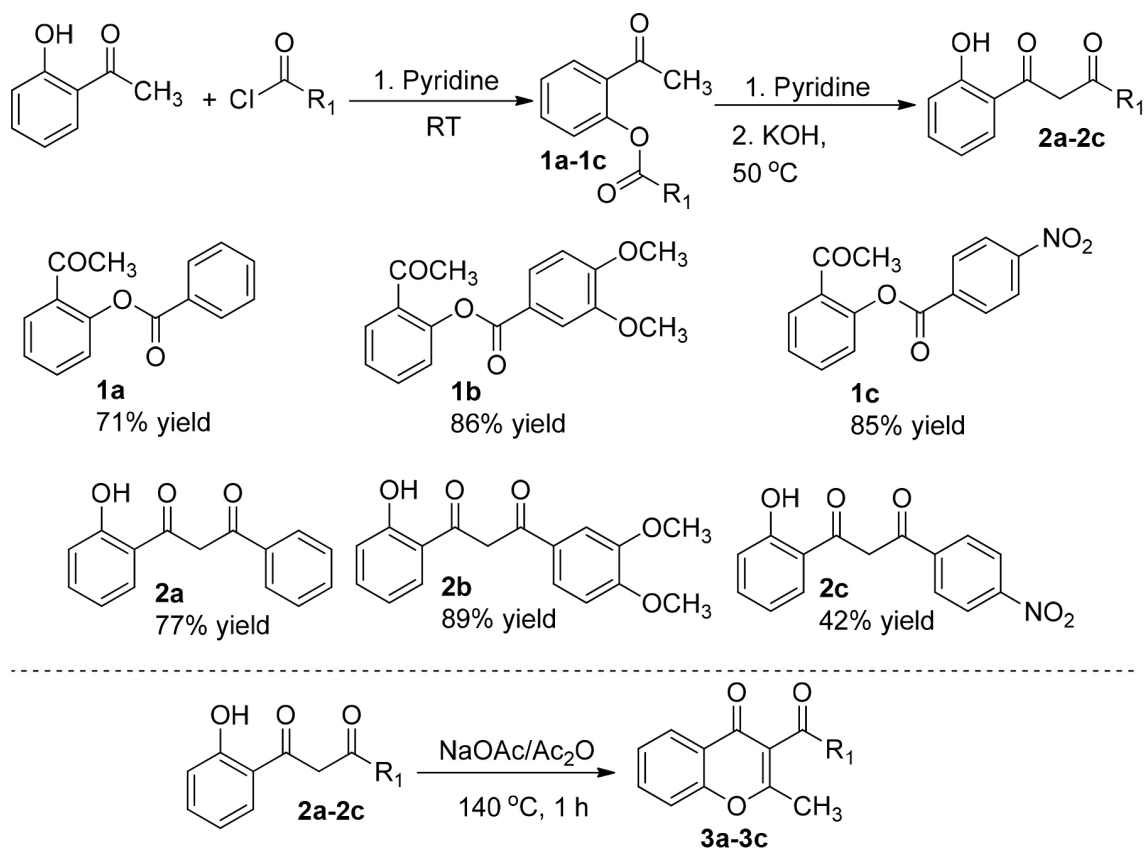<smiles>Cc1oc2ccccc2c(=O)c1C(=O)c1ccccc1</smiles>

3a: $16 \%$ yield LogP: 3.21<smiles>COc1ccc(C(=O)c2c(C)oc3ccccc3c2=O)cc1OC</smiles>

3b: $77 \%$ yield LogP: 2.86<smiles>Cc1oc2ccccc2c(=O)c1C(=O)c1ccc([N+](=O)[O-])cc1</smiles>

3c: $95 \%$ yield LoaP: 3.17

Scheme 1. Synthesis of chromone derivatives: 1a-1c pyridine, room temperature, $15 \mathrm{~min} ; \mathbf{2 a - 2 c}$ pyridine, $\mathrm{KOH}, 50{ }^{\circ} \mathrm{C}, 15 \mathrm{~min} ; \mathbf{3 a - 3 c} \mathrm{NaOAc} / \mathrm{Ac}_{2} \mathrm{O}$, $140{ }^{\circ} \mathrm{C}, 1 \mathrm{~h}$

$1700 \mathrm{~cm}^{-1}$ indicated the presence of a conjugated ketone and IR bands ca. 3000, 1650, 1500 and $1450 \mathrm{~cm}^{-1}$, were attributed to the $\mathrm{C}-\mathrm{H}$ bond and $\mathrm{C}=\mathrm{C}$ of the benzenoid ring. The proton NMR spectra displayed characteristic singlet resonance signals corresponding to the methyl group at approximately $2.5 \mathrm{ppm}$. In the ${ }^{13} \mathrm{C}$ spectrum, the chemical shift for the methyl carbon was recorded at ca. $30 \mathrm{ppm}$. The lipophilicity of the 3-benzoylchromone derivatives $\mathbf{3 a - 3} \mathbf{c}$ is important for gauging how well these compounds will be absorbed by the skin. The Log P values for each compound are presented in Scheme 1. The Log P of $3 \mathbf{a}$ is $3.21, \mathbf{3 b}$ is 2.86 and $3 \mathbf{c}$ is 3.17 . A $\log P>1$ is indicative of lipophilic character and for a $\log \mathrm{P}<1$, the molecule is considered to have more hydrophilic character. Interestingly, oxybenzone has been confirmed by in vivo studies to be absorbed transdermally ${ }^{13,14}$ and the $\log$ P for this compound was calculated to be 3.37 which was very similar to 3-benzoylchromones described in this study. The Log P octanol-water partition coefficient was calculated using Molinspiration Interactive Log $\mathrm{P}$ calculator. ${ }^{26}$

\section{UV-Vis absorption spectra of the compounds in solution}

The absorption spectra of compounds $\mathbf{3 a - 3}$ in solution are shown in Figure 1. Compounds 3a-3c exhibited high

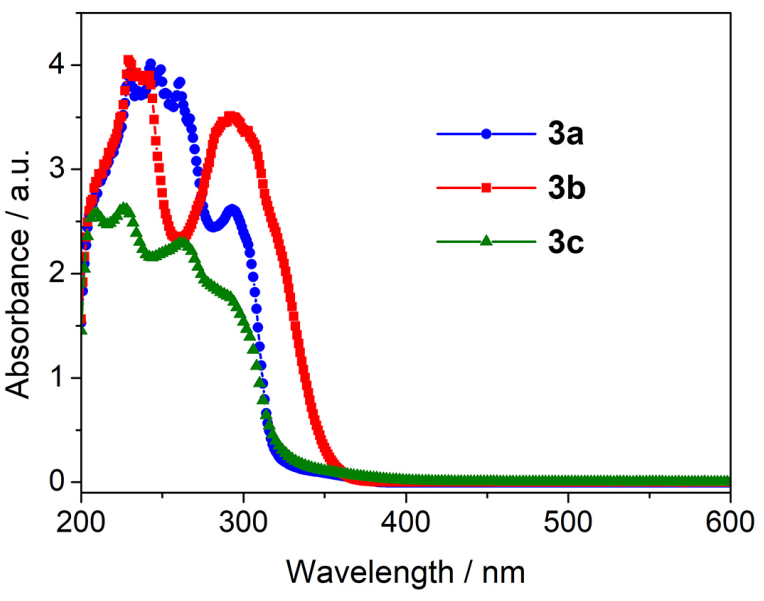

Figure 1. UV-Vis absorption spectra of the compounds $\mathbf{3 a - 3} \mathbf{c}$ in solution.

absorbance in the UVC, UVB and UVA region, with absorption maxima at around $230 \mathrm{~nm}$ (UVC) and shoulders at about $300 \mathrm{~nm}$ (UVB and UVA), suggesting that the compounds are potential candidates for UV photoprotection products, since a substance to be applied in a sunscreen formulation should present a broad spectrum UVC, UVB and UVA. Using the Beer-Lambert Law, A $(\lambda)=\varepsilon(\lambda)$ lc, where $A$ is the absorbance, $c$ is the concentration in $\mathrm{mol} \mathrm{L}^{-1}$ and $l$ is the path length in $\mathrm{cm}$, the maxima molar absorption coefficients $(\varepsilon)$ of the compounds $\mathbf{3 a}, \mathbf{3 b}$ and $\mathbf{3} \mathbf{c}$ were found 
to be $1.0 \times 10^{4}\left(\varepsilon_{1}\right.$ in $\left.240 \mathrm{~nm}\right), 1.3 \times 10^{4}\left(\varepsilon_{2}\right.$ in $\left.230 \mathrm{~nm}\right)$ and $0.8 \times 10^{4}\left(\varepsilon_{3}\right.$ in $\left.225 \mathrm{~nm}\right) \mathrm{L} \mathrm{mol}^{-1} \mathrm{~cm}^{-1}$, respectively. ${ }^{13,14}$ Over the years, the development of ideal photoprotectors to obtain safe and effective formulations included those that provide broad UV protection..$^{31,32}$

\section{In vitro determination of the sun protection factor (SPF)}

The SPF was evaluated by the Mansur method using a UV spectrophotometer. The values of the acquired absorbance values were placed in equation $\mathrm{S} 1$ and used to calculate the SPF values which are presented in Table 2. Neo Heliopan ${ }^{\circledast}$ and benzophenone-3 have been used as positive controls. According to Table 2, compounds 3a and $\mathbf{3 b}$ showed higher SPF values than benzophenone-3 at the tested concentrations. The SPF of benzophenone-3 (S2) at a concentration of $0.1 \mathrm{mg} \mathrm{mL}^{-1}$ was reported to be 19.731..$^{13,14}$ By analysis of the obtained data, we verified that compounds $\mathbf{3 a}$ and $\mathbf{3 b}$ presented SPF proportional to the analyzed concentrations. The results are promising and suggest that these are viable candidates to act as a UV filter in sunscreen formulations.

\section{Evaluation of photostability}

Compounds $\mathbf{3 a - 3 \mathbf { c }}$ were analyzed separately and in triplicate at room temperature in the photostability assay. The samples were dissolved in methanol, resulting in solutions at concentration of $0.1 \mathrm{mg} \mathrm{mL}^{-1}$ before being exposed to UV radiation (at $365 \mathrm{~nm}$ ) for $1 \mathrm{~h}$ and $20 \mathrm{~min}$. The temperature of the experiment was constant over the total period of the study. Figure 2 shows the behavior of the compounds before and after their exposure to UV radiation for different time. The inserts of Figure 2 show the intensity of absorption of the compounds versus exposure time to UV radiation. Compounds $3 \mathbf{a}$ and $\mathbf{3 b}$ showed the smallest variation of absorbance during the exposure time to UV radiation. Compound $3 \mathbf{c}$ showed a decrease in absorbance over time and indicating possible degradation under UV exposure.

\section{Cell viability}

Compounds 3a and $\mathbf{3 b}$ displayed no cytotoxic effect towards MRC-5 human fibroblasts at tested concentrations, according to ISO10993-5:2009. ${ }^{33}$ On the other hand, compound 3c exhibited higher toxicity, since at its lowest concentration 3c was above 70\% viability (Figure 3). Therefore, these results indicate safety of compounds $\mathbf{3 a}$ and $\mathbf{3 b}$ at the concentration used to determine its SPF value $\left(100 \mu \mathrm{g} \mathrm{mL}^{-1}\right)$, but compound $\mathbf{3 c}$ was, in contrast, toxic at this concentration. In view of these cytotoxicity results, along with the SPF values (Table 2), compound $\mathbf{3 c}$ has the least potential for further applications and compounds $\mathbf{3 a}$ and $\mathbf{3 b}$ were therefore selected for the development of nanoemulsions.

\section{Nanoemulsions}

Macroscopically, after $24 \mathrm{~h}$ of preparation, the nanoemulsions remained stable and with a slightly milky appearance, except the S2 standard, which had a milkier appearance, according to Figure S9 (SI section). As can be seen in Table 3, nanoemulsions containing compounds $\mathbf{3 a}$, 3b and standard S1 showed an average droplet size of less than $150 \mathrm{~nm}$ and the nanoemulsion containing the standard S2 had a size of $433.70 \pm 46.36 \mathrm{~nm}$. The average droplet size values obtained are in accordance with the size range established for nanoemulsions. ${ }^{34}$ The polydispersity index (PI) values of nanoemulsions $\mathbf{3 a}, \mathbf{3 b}$ and $\mathrm{S} 1$ were lower than 0.3 , considering monodispersed, ${ }^{34}$ which showed high droplets size homogeneity. The droplet size of an emulsion depends on the emulsification method used. ${ }^{35}$ The results demonstrated the efficiency of the phase inversion emulsification method in obtaining nanoemulsions with compounds $\mathbf{3 a}$ and $\mathbf{3 b}$.

The small size of droplets present in a nanoemulsion stabilizes it against gravitational phase separation and flocculation, ${ }^{36}$ besides allowing a more uniform deposition on the skin surface, ${ }^{36}$ promoting the formation

Table 2. SPF compounds $\mathbf{3 a - 3} \mathbf{c}$ and standards

\begin{tabular}{|c|c|c|c|c|c|}
\hline \multirow{2}{*}{$\begin{array}{l}\text { Concentration / } \\
\left(\mathrm{mg} \mathrm{mL}^{-1}\right)\end{array}$} & \multicolumn{5}{|c|}{ SPF-UVB compounds } \\
\hline & $3 \mathbf{a}$ & $\mathbf{3 b}$ & $3 c$ & $\mathrm{~S} 1$ & $\mathrm{~S} 2$ \\
\hline 0.025 & $10.728 \pm 0.004^{\mathrm{a}}$ & $11.035 \pm 0.012^{\mathrm{b}}$ & $5.892 \pm 0.010^{c}$ & $34.912 \pm 0.063^{\mathrm{d}}$ & $10.774 \pm 0.049^{\mathrm{a}}$ \\
\hline 0.030 & $11.787 \pm 0.004^{\mathrm{a}}$ & $10.157 \pm 0.018^{\mathrm{b}}$ & $8.856 \pm 0.003^{c}$ & $35.264 \pm 0.053^{\mathrm{d}}$ & $11.607 \pm 0.150^{\mathrm{a}}$ \\
\hline 0.050 & $14.053 \pm 0.015^{\mathrm{a}}$ & $22.515 \pm 0.007^{b}$ & $11.692 \pm 0.006^{c}$ & $36.027 \pm 0.079^{d}$ & $15.533 \pm 0.001^{\mathrm{e}}$ \\
\hline 0.070 & $20.312 \pm 0.003^{\mathrm{a}}$ & $26.528 \pm 0.008^{b}$ & $14.157 \pm 0.011^{\mathrm{c}}$ & $36.492 \pm 0.059^{\mathrm{d}}$ & $17.596 \pm 0.004^{\mathrm{e}}$ \\
\hline 0.100 & $27.436 \pm 0.032^{\mathrm{a}}$ & $28.844 \pm 0.044^{\mathrm{b}}$ & $16.775 \pm 0.002^{\mathrm{c}}$ & $36.817 \pm 0.090^{\mathrm{d}}$ & $19.731 \pm 0.006^{\mathrm{e}}$ \\
\hline
\end{tabular}

a-e Indicate $p<0.05$ at the same line by one-way ANOVA test; SPF: solar protection factor; chromones: 3a-3c; S1 (standard 1): Neo Heliopan ${ }^{\circledR}$; $\mathrm{S} 2$ (standard 2): benzophenone-3; results expressed as mean \pm standard deviation. 

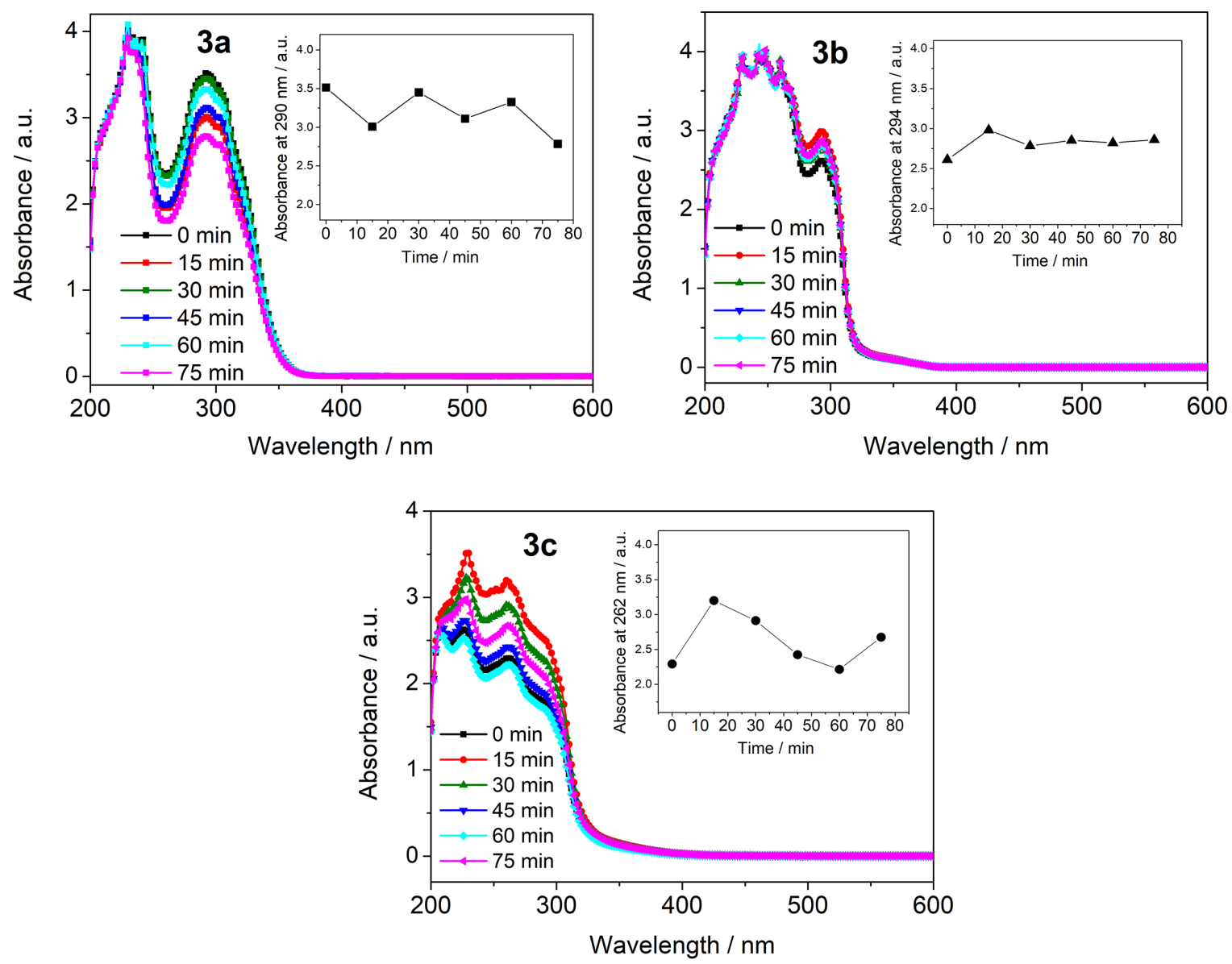

Figure 2. Graphs of photostability of the compounds $\mathbf{3 a - 3}$ after exposure to UV radiation in different times. The inserts show the intensity of absorption versus exposure time to $\mathrm{UV}$ radiation.

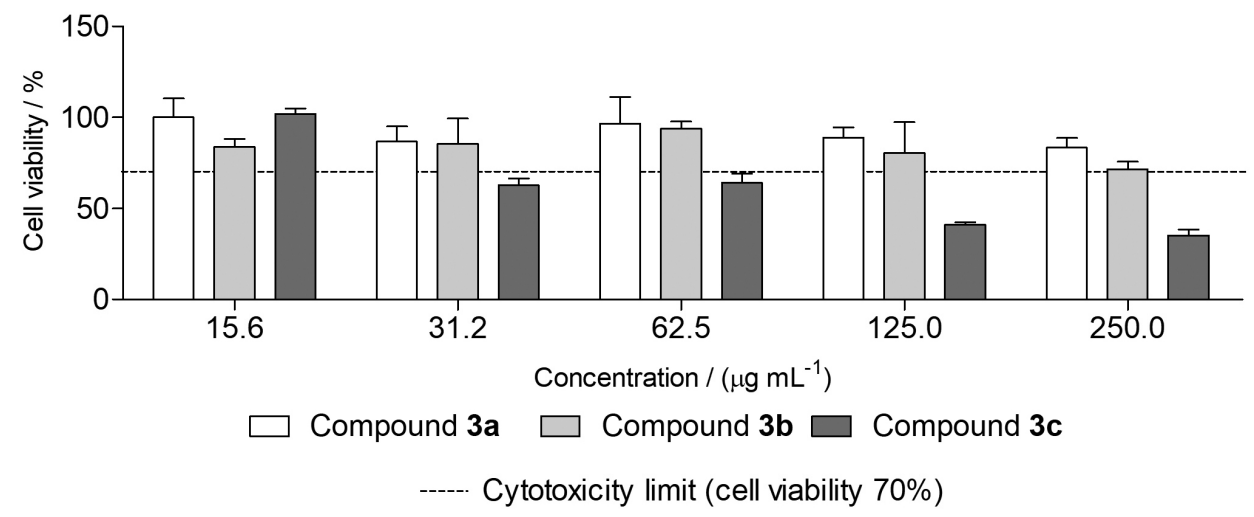

Figure 3. Cytotoxicity of the compounds 3a-3c.

of a continuous film, and consequently, improving the effectiveness of the nanoemulsion in protecting against UVA and UVB rays..$^{14}$

The zeta potential (surface charge) of a nanoformulation can interfere with its stability. If the value of the zeta potential is relatively high (>30 mV in modulus), the repulsive forces exceed the attractive forces of van der Waals, culminating in obtaining an electrostatically stable system. Thus, a greater electrostatic repulsion between the nanoparticles reduces the probability of formation of aggregates, preventing the flocculation of the nanoemulsion from surface ${ }^{37}$ All nanoemulsions produced had zeta potential values greater than $-30 \mathrm{mV}$, which contributes to maintaining the stability of these systems. After $24 \mathrm{~h}$, the two nanoemulsions were read to analyze the SPF using the Mansur formula, as shown in Table 4.

The data in Table 4 leads us to conclude that among the chromone derivatives investigated, the most promising 
Table 3. Average size, polydispersity index and zeta potential of nanoemulsions with compound $\mathbf{3 a}$, compound $\mathbf{3 b}$ and standards

\begin{tabular}{lccc}
\hline Nanoemulsion & Average size \pm SD $/ \mathrm{nm}$ & PI \pm SD & Zeta potential \pm SD $/ \mathrm{mV}$ \\
\hline 3a & $144.40 \pm 0.31$ & $0.28 \pm 0.03$ & $-36.00 \pm 1.16$ \\
3b & $148.00 \pm 0.70$ & $0.26 \pm 0.02$ & $-36.70 \pm 1.50$ \\
S1 & $135.60 \pm 1.57$ & $0.20 \pm 0.01$ & $-30.90 \pm 1.94$ \\
S2 & $433.70 \pm 46.36$ & $0.57 \pm 0.04$ & $-35.70 \pm 1.85$ \\
\hline
\end{tabular}

SD: standard deviation; PI: polydispersity index; chromones: 3a and 3b; S1 (standard 1): Neo Heliopan ${ }^{\oplus}$; S2 (standard 2): benzophenone-3.

Table 4. SPF of the nanoemulsions of compounds and standards

\begin{tabular}{lcccc}
\hline \multirow{2}{*}{ Concentration / $\left(\mathrm{mg} \mathrm{mL}^{-1}\right)$} & \multicolumn{4}{c}{ Nanoemulsion } \\
\cline { 2 - 5 } & S1 & S2 & 3a & 3b \\
\hline 0.025 & $36.348 \pm 0.001^{\mathrm{a}}$ & $11.130 \pm 0.008^{\mathrm{b}}$ & $12.894 \pm 0.001^{\mathrm{c}}$ & $13.889 \pm 0.001^{\mathrm{d}}$ \\
0.030 & $36.917 \pm 0.001^{\mathrm{a}}$ & $13.118 \pm 0.001^{\mathrm{b}}$ & $19.561 \pm 0.001^{\mathrm{c}}$ & $23.745 \pm 0.051^{\mathrm{d}}$ \\
0.050 & $38.508 \pm 0.002^{\mathrm{a}}$ & $13.343 \pm 0.001^{\mathrm{b}}$ & $24.560 \pm 0.001^{\mathrm{c}}$ & $27.882 \pm 0.037^{\mathrm{d}}$ \\
0.070 & $43.492 \pm 0.001^{\mathrm{a}}$ & $20.769 \pm 0.001^{\mathrm{b}}$ & $35.439 \pm 0.006^{\mathrm{c}}$ & $37.938 \pm 0.003^{\mathrm{d}}$ \\
0.100 & $45.115 \pm 0.002^{\mathrm{a}}$ & $22.954 \pm 0.004^{\mathrm{b}}$ & $37.98 \pm 0.001^{\mathrm{c}}$ & $38.555 \pm 0.002^{\mathrm{d}}$ \\
\hline
\end{tabular}

Chromones: 3a and 3b; S1 (standard 1): Neo Heliopan ${ }^{\circledast} ;$ S2 (standard 2): benzophenone-3. Results expressed as mean \pm standard deviation; different letters indicate $p<0.05$ at the same line by one-way ANOVA test.

was the nanoemulsion containing $\mathbf{3 b}$. At the highest concentration of $0.1 \mathrm{mg} \mathrm{mL}^{-1}, \mathbf{3 a}$ has an SPF of 37.98 and the $\mathbf{3 b}$ has an SPF of 38.55 .

\section{Conclusions}

The photoprotection study performed according to the Mansur methodology showed promising applications for compound $\mathbf{3 b}$, which presented SPF values similar to benzophenone-3. In addition, the photostability test suggests that compound $\mathbf{3 b}$ is stable with only a small drop in its absorption in the first $15 \mathrm{~min}$ of exposure to UV light. 3-Benzoylchromone derivatives $\mathbf{3 a}$ and $\mathbf{3 b}$ are promising compounds that can be incorporated into formulations of sunscreens. Chromone $\mathbf{3 b}$, as well as compound 3a, displayed no cytotoxic effect to MRC-5 human fibroblasts at tested concentrations, indicating a great potential for clinical trials. Finally, compounds 3a and $\mathbf{3 b}$ were incorporated into nanoemulsions that were stable, with a small average droplet size and high SPF value, being strong candidates for the development of sunscreens formulations.

\section{Supplementary Information}

NMR spectra used in the characterization of the compounds are available free of charge at http://jbcs.sbq.org.br as PDF file.

\section{Acknowledgments}

The authors gratefully acknowledge the generous financial support from the Federal University of Ouro
Preto (UFOP), FAPEMIG and the Conselho Nacional de Desenvolvimento Científico e Tecnológico (CNPq). The authors gratefully acknowledge PROPP/UFOP (No. 23109.000928/2020-33). The authors would like to acknowledge the Laboratório Multiusuário de Proteômica e Biomoléculas (LMU-ProtBio), at the Federal University of Ouro Preto for providing excellent mass spectrometry services.

\section{Author Contributions}

Amanda S. Antunes, Ricardo G. Penido, Ana Paula Gouveia and Gabriela M. Diogo were responsible for data curation, investigation, synthesis and characterization of organic compounds; Jason G. Taylor for conceptualization, data curation, investigation, validation; Orlando D. H. dos Santos and Fernanda B. Perasoli for formal analysis funding acquisition and validation; Paula M. A. Vieira, Lucas R. D. Sousa, Tatiane R. Amparo for data curation and resources; Thiago Cazati for data curation, formal analysis funding acquisition, investigation, resources, validation and writing original draft; Viviane M. R. dos Santos for investigation, project administration resources, writing original draft and writing-review and editing.

\section{References}

1. Yang, S. I.; Liu, S.; Brooks, G. J.; Lanctot, Y.; Gruber, J. V.; J. Cosmet. Dermatol. 2018, 17, 518.

2. Borase, H. P.; Patil, C. D.; Salunke, R. B.; Suryawanshi, R. K.; Salunke, B. K.; Patil, S. V.; Int. J. Cosmet. Sci. 2014, 36, 571.

3. Narendhirakannan, R. T.; Hannah, M. A. C.; Indian J. Clin. Biochem. 2013, 28, 110. 
4. Polonini, C. P.; Lopes, R. S.; Beatriz, A.; Gomes, R. S.; Silva, A. O.; de Lima, R. V.; Nunes, G. A.; Brandão, M. A. F.; Raposo, N. R. B.; de Lima, D. P.; Quim. Nova 2014, 37, 1004.

5. Schlumpf, M.; Cotton, B.; Conscience, M.; Haller, V.; Steinmann, B.; Lichtensteiger, W.; Environ. Health Perspect. 2011, 109, 239.

6. do Nascimento, M. S. S. T.: Desenvolvimento Tecnológico de Formulação Fotoprotetora a Base de Produtos Naturais; MSc Dissertation, Universidade Federal do Mato Grosso do Sul, Campo Grande, Brazil, 2014, available at http://docplayer.com. br/32474268-Desenvolvimento-tecnologico-de-formulacaofotoprotetora-a-base-de-produtos-naturais.html, accessed in May 2021.

7. Vicentini, F. T. M. C.: Efeito Fotoquimioprotetor de Quercetina Incorporada em Microemulsão contra os Danos na Pele Causados pela Radiação Ultravioleta; $\mathrm{PhD}$ thesis, Universidade de São Paulo, Ribeirão Preto, 2009, available at https://www. teses.usp.br/teses/disponiveis/60/60137/tde-15042009-162535/ pt-br.php, accessed in May 2021.

8. Leite Filho, C. A.; Reis, S. A. G. B.; Rolim, L. A.; Araújo, C. R. M.; Gonsalves, A. A.; Rev. Virtual Quim. 2016, 8, 2057.

9. Bacardit, A.; Cartoixà, X.; J. Phys. Chem. Lett. 2020, 11, 1209.

10. Ergindemir, H. N.; Aker, A.; Hamitbeyli, A.; Ocal, N.; Molecules 2016, 21, 718 .

11. dos Santos, J. A.; Polonini, H. C.; Suzuki, É. Y.; da Silva, A. D.; Steroids 2015, 98, 114.

12. Reis, J. S.; Correa, M. A.; Chin, C. M.; dos Santos, J. L.; Bioorg. Med. Chem. 2014, 22, 2733.

13. Gonçalves, M. C.; Rossoni Jr., J.; Rabelo, A. C. S.; Costa, D. C.; Cazati, T.; Taylor, J. G.; dos Santos, V. M. R.; Rev. Virtual Quim. 2018, 10, 600.

14. Gonçalves, M. C.; dos Santos, V. M. R.; Taylor, J. G.; Perasoli, F. B.; dos Santos, O. D. H.; Rabelo, A. C. S.; Rossoni Jr., J. V.; Costa, D. C.; Cazati, T.; Quim. Nova 2019, 42, 365.

15. Cabral, L. D. S.; Pereira, S. O.; Partata, A. K.; Infarma Cienc. Farm. 2013, 25, 107.

16. Singh, R.; Lillard, J. W.; Exp. Mol. Pathol. 2009, 86, 215.

17. Mansur, J. S.; Breder, M. V. R.; Mansur, M. C. A.; Azulay, R. D.; An. Bras. Dermatol. 1986, 61, 121.

18. Menezes, J. C. L.; Vaz, L. B. A.; de Abreu, V. P. M.; da Silva, F. K.; Carneiro, C. M.; Taylor, J. G.; Molecules 2015, $20,43$.
19. de Souza, A. A. N.; Xavier, V. F.; Coelho, G. S.; Sales Jr., P. A.; Romanha, A. J.; Murta, S. M. F.; Carneiro, C. M.; Taylor, J. G.; J. Braz. Chem. Soc. 2018, 29, 269.

20. Bapna, M.; Nema, R. K.; Asian J. Chem. 2008, 20, 6022.

21. Barros, A. I. R. N.; Silva, A. M. S.; Monatsh. Chem. 2006, 137, 1505.

22. Lee, J.-I.; Son, H.-S.; Park, H.; Bull. Korean Chem. Soc. 2004, $25,1945$.

23. Jain, A. C.; Sarpal, P. D.; Seshadri, T. R.; Indian J. Chem. 1965, $3,369$.

24. Lin, A. J.; Hoch, J. M.; Arzneim. Forsch. 1984, 34, 640.

25. Baker, W.; Harbone, J. B.; Ollis, W. D.; J. Chem. Soc. 1952, 1294.

26. Molinspiration Cheminformatics, v2015.01; Bratislava University, Slovak Republic, 1986, available at http://www. molinspiration.com/, accessed in May 2021.

27. Poprawa, A. K.; Kwiecie, A.; Opoka, W.; Pharmaceutics 2020 , $12,10$.

28. Skehan, P.; Storeng, R.; Scudiero, D.; Monks, A.; McMahon, J.; Vistica, D.; Warren, J. T.; Bokesch, H.; Kenney, S.; Boyd, M. R.; J. Natl. Cancer Inst. 1990, 82, 1107.

29. http://www.modcs.org/wp-content/uploads/2015/01/ANOVAslides.pdf, accessed in May 2021.

30. Radushev, D.; Prism 5 for Windows, version 5.01; GraphPad Software, United States, 2007.

31. Lim, H. W.; Sage, R. J.; Dermatol. Ther 2010, 23, 1.

32. Balogh, T. S.; Pedriali, C. A.; Baby, A. R.; Velasco, M. V. R.; An. Bras. Dermatol. 2011, 86, 732.

33. ISO 10993-5:2009: Biological Evaluation of Medical DevicesPart 5: Tests for in vitro Cytotoxicity, ISO: Geneva, 2009.

34. Bouchama, F.; Aken, G.; Van, A. A. J.; Koper, G. J.; Colloids Surf., A 2003, 231, 11.

35. Klassen, P. L.; George, Z.; Warwick, J.; Georgiadou, S.; Colloids Surf., A 2014, 455, 1.

36. Mahdi, E. S.; Noor, A. M.; Sakeena, M. H.; Abdullah, G. Z.; Abdulkarim, M. F.; Sattar, M. A.; Int. J. Nanomed. 2011, 6, 2499.

37. Marzukia, N. H. C.; Wahaba, R. A.; Hamid, M. A.; Biotechnol. Biotechnol. Equip. 2019, 33, 779.

Submitted: February 28, 2021 Published online: May 14, 2021 